\title{
Colorectal Cancer pT4a TNM Finding v7
}

National Cancer Institute

\section{Source}

National Cancer Institute. Colorectal Cancer pT 4a TNM Finding v7. NCI Thesaurus. Code C89946.

Colorectal cancer with penetration to the surface of the visceral peritoneum. (from AJCC 7th Ed.) 